\title{
The Effects of Using Information Transfer Technique Toward Students' Listening Comprehension
}

\author{
Ferri Yonantha ${ }^{1}$ \\ Mohd. Izzat Khan ${ }^{2}$ \\ ${ }^{1}$ Corresponding author, English Education Department, STAIN Sultan Abdurrahman, Bintan, Indonesia; \\ ferri.yonantha@stainkepri.ac.id \\ ${ }^{2}$ English Education Department, STAIN Sultan Abdurrahman, Bintan, Indonesia; m.izzatkhan890@gmail.com
}

\begin{abstract}
This study aimed to investigate the information about the students' listening comprehension taught by using Information Transfer technique for experimental class and traditional teaching technique for control class. Then, this study was also to find out whether there was a significant effect of using Information Transfer technique toward students' listening comprehension. The study used a quasi-experimental-nonequivalent control group design. The participants consisted of two classes of the first-year students of Junior High School, 35 students for experimental class and 35 students for control class. The data were collected by using pre-test before the treatment and post-test after the treatment. The study findings showed that the improvement could be seen from the score test. The result was analyzed statistically by using paired and independent sample t-test through SPSS 16. The result found that there was a significant effect of using Information Transfer toward students' listening comprehension.
\end{abstract}

Keywords: Information Transfer Technique; Listening Comprehension, Teacher professional development

\section{Introduction}

Learning English cannot be separated from education in Indonesia. English is learned as a foreign language involving four skills: listening, speaking, reading and writing. Listening is one of the most important activities students engage in (Dale and Wolf, 2006:146). Many activities require listening as one crucial part showing that listening is one of four skills which is useful to be mastered. Many knowledge disciplines in English have encouraged most of the students to be able to understand and even comprehend what they listen to. As what Morley stated in Murcia (2001:70) that people listen twice as much as speak, four times more than read, and five times more than write.

Besides, listening is as an essential skill that should be completed with comprehension. Listening comprehension is psychomotor process of receiving sound waves through the ears and transmitting nerve impulses to the brain (Brown, 2000:249). It means that listening needs 
complex ability of analysis not only listen to what speaker says but also to know the meaning of that utterance. Listening comprehension requires the students to listen selectively to what speaker says because the information is put in. In the context of the task, the students must not know all what was said but they must be able to finish all tasks successfully. As what Brown (1990:148) said, "it does not matter whether or not the students have understood all the details of what was said. All the matter is that the students have been able to construct enough of a reasonable interpretation to make a decent effort at completing the task successfully".

Teaching will be more effective if the teacher uses technique(s) to achieve the teaching goals. Information Transfer technique, found by Palmer in Nation and Newton (2009:47), is a technique used to improve students listening comprehension where learners reproduce the message they hear in a new form, for example when they listen and respond by ordering a set of pictures, completing a map, drawing a picture or completing a table. A key characteristic of such activities is that they involve a change in the form of the message but the message remains the same.

In addition, Storla in Thi and Loan (1995:97) stated that information technique is translating data from one to another. The students move from the reading or listening text to graphic stimuli or visual like chart, graph, diagram, figure, maps, etc. Brown (2003:127) also stated that Information Transfer technique in which aurally processed information must be transferred to a visual representation, such as labelling a diagram, identifying an element in a picture, completing a form, or showing routes on map. The students are expected to transform and reinterpret the language or information (Brown,1994:143). Palmer in Nation stated again that during the transfer of information remains substantially the same but the form of the information changes (1988:17). In a receptive Information Transfer exercise learners change spoken or written information into a diagram, chart or picture. By making this chance the learners show that they have understood the information and that their understanding is deep enough to adapt in some way. Thus, Information Transfer technique is converting the content of the verbal language form into the non-verbal language form and vice versa to make the information easy to understand and to convey.

The use of data in Information Transfer technique is very common in our daily lives and has many advantages as what the Palmer in Thi and Nguyen thi Loan (1995:97-98) stated the advantages are outlined below:

\section{Authenticity}

Firstly, Information Transfer is an authentic task that is often used in an English' speaking environment by native speakers in the normal course of their everyday lives. Let's take the train timetables as an example. The railway clerk at the enquiries office constantly transfers his own semi-diagrammatic timetable into linguistic information for people who telephone to ask for train times. These people also probably note down that information in a semischematic way rather than in its fully linguistic form.

\section{Communicative tasks}

Information Transfer activities are also communicative tasks. When customers book a flight at the travel agent, the clerk will interpret the information on the computer screen for them and use information transfer in communicating and offering help. 


\section{Repetitive tasks}

Normally, the information presented in a diagrammatic form or semi-diagrammatic form is frequently a concentrated collection of similar items of information, for example, repeatedly the train time table shows us when the train will depart from, stop at, and arrive at a limited number of places. This means that the linguistic equivalent may well be expressed by repetition of a certain structure. In this way, Information Transfer activities can be very appropriate to a controlled practice stage of a lesson.

\section{Productive tasks}

An Information Transfer exercise, such as an information-gap task, usually provides students only with the bare bones of information - they must supply the additional information, often to a partner. Thus, if it is appropriately staged, information transfer can fit into the free production stage of a lesson.

A number of researchers had conducted some studies related to improving listening comprehension through using technique(s) and the use of Information Transfer technique itself. Vien Truon (1999) conducted a research related to an application of the Information Transfer technique in teaching reading comprehension in Vietnamese secondary school classrooms of English. In this term she emphasized the use of this technique to improve students' comprehension on the receptive skills. Sumiati (2011) then conducted a research entitled "The Effect of Using Three Step Interview Technique toward Students' Listening Comprehension at the First Year of State Senior High School Dharma Pendidikan Kempas District of Indragiri Hilir Regency". The design of the research is a quasi-experimental research type Non-equivalent Control Group Design. The finding showed that there was an improvement by having $\mathrm{Ha}$ is accepted.

Listening is one of the skills that must be taught and learned by the students in the senior high school. There are two basic competences required in listening for the first year of senior high school. The competences are the students are able to understand meaning in formal transactional/interpersonal conversation in daily life context and also the students are able to respond meaning in simple monologue text in spoken or written form accurately in recount, narrative, and procedure.

Based on the preliminary study of the first year students at Al Madinah Islamic Junior High School Tanjungpinang it was found that most of the students were not able to identify the gist of what they listen to, specific information in listening materials, what the speakers mean, to catch the points clearly what they have heard, and to retell what they have listened whether in spoken or written form. Besides, the English teacher taught the students by using traditional teaching technique such as discussion like listening to audio cassette and the students were asked some questions related to what they have listened and the English teacher used dictation as the technique. Therefore, the writer used a technique to improve students' listening comprehension through using Information Transfer technique.

According to Nation and Newton (2009: 47-48), the steps of applying Information Transfer technique are as follows:

a. The teacher introduces and explains the Information Transfer technique.

b. The teacher prepares the students to listen and spreads the transfer diagrams to them.

c. Learners begin by listening to audio cassette and then completing some kinds of Information Transfer diagram by listening to a description or dialogue and label a diagram or fill in a chart or table while they listen. Such as: 
Table 1. Information Transfer Worksheet

\begin{tabular}{llll}
\hline Item & Who & What & \\
\hline 1 & & \\
\hline $\mathbf{3}$ & & \\
\hline 4 & & \\
\hline
\end{tabular}

d. They then take part in a writing activity in which they retell the main ideas in the text using the diagram as a guide. In this way, Information Transfer provides an intermediary bridge or link between input and output which discourages learners from relying too heavily on direct copying from the original text, but which still provides them with a conceptual scaffold for rebuilding the original text in their own words or for another purpose.

e. Teacher repeats the audio cassete into several times.

f. Teacher gives evaluation to students by discussing together and checking their works.

\section{Method}

This research was an experimental research. Gay and Airasian (2000:367) stated, the experimental research is the only type of research that can test hypotheses to establish the use and affection of relationship. Furthermore, the design of the research was a Quasy experimental research - non-equivalent control group design, which is intended to find out the influence of using Information Transfer Technique toward students' listening comprehension. Quasy experimental design is experimental situation in which the researcher assigns, not randomly, participants to groups because the experimenter cannot artificially create groups for the experiment. (Cresswell, 2008:645).

Then, this research also used two classes as sample. The first class functioned as experimental class treated by using Information Transfer technique. The second was the control class treated without using Information Transfer technique.

\subsection{Respondents}

The research was conducted at Al Madinah Islamic Junior High School Tanjungpinang. The writer took VII Zainab Binti Jahsy as an experimental class and VII Ali Bin Abi Thalib as a control class where each class consisted of 35 students.

\subsection{Instruments}

In order to get the data to support this study, the writer used test to find out the effect of using information technique toward listening comprehension of first year students at Al Madinah Islamic Junior High School Tanjungpinang, the writer administered the test to assess students' listening comprehension. The test was done into two stages. The first was pretest done before doing the treatments. The second was posttest done after doing the treatments. The researcher took the total score from the result of the listening comprehension test. The classification of the students' score is shown below (Arikunto, 2009:245). 
Table 2. The Score Classification

\begin{tabular}{cc}
\hline Score & Categories \\
\hline $\mathbf{8 0}-\mathbf{1 0 0}$ & Very good \\
\hline $\mathbf{6 6}-\mathbf{7 9}$ & Good \\
\hline $\mathbf{5 6}-\mathbf{6 5}$ & Sufficient \\
\hline $\mathbf{4 0}-\mathbf{5 5}$ & Less \\
\hline $\mathbf{3 0}-\mathbf{3 9}$ & Fail \\
\hline
\end{tabular}

\subsection{Data Analysis}

In finding out whether or not there is a significant effect of using Information Transfer techique towards listening comprehension of the first year students at Al Madinah Islamic Junior High School Tanjungpinang, the writer used Independent Sample $t_{\text {test }}$ analyzed by using SPSS 16.0 version. Hartono stated that independent sample $t_{\text {test }}$ is to find out whether there is significant difference or there is no significant difference between two or more variables (Hartono, 2010:177-179). Gay and Airasian (2000:484) added that the t-test for independent sample is used to determine whether there is probably a significant difference between the means of two independent samples.

The t-table has the function to see if there is a significant difference among the mean of the score of both experimental and control group. The t-obtained value is consulted with the value of t-table at the degree of freedom $(\mathrm{df})=(\mathrm{N} 1+\mathrm{N} 2)-2$ which is statistically hypothesis:

Ha: to $>$ t-table

Ho: to $<\mathrm{t}$-table

$\mathrm{Ha}$ is accepted if to $>\mathrm{t}$-table or there is a significant effect of using Information Transfer technique towards students' listening comprehension.

Ho is accepted if to $<\mathrm{t}$-table or there is no effect of using Information Transfer technique towards students' listening comprehension.

\section{Finding and Discussion}

$\mathbf{H}_{\mathbf{0}} 1$ : There was no significant difference of listening comprehension before being taught by using information transfer technique for experimental class and traditional teaching technique for control class.

It can be seen from Table 3 below. 
Table 3. Independent sample test from pre-test score of experimental and control class

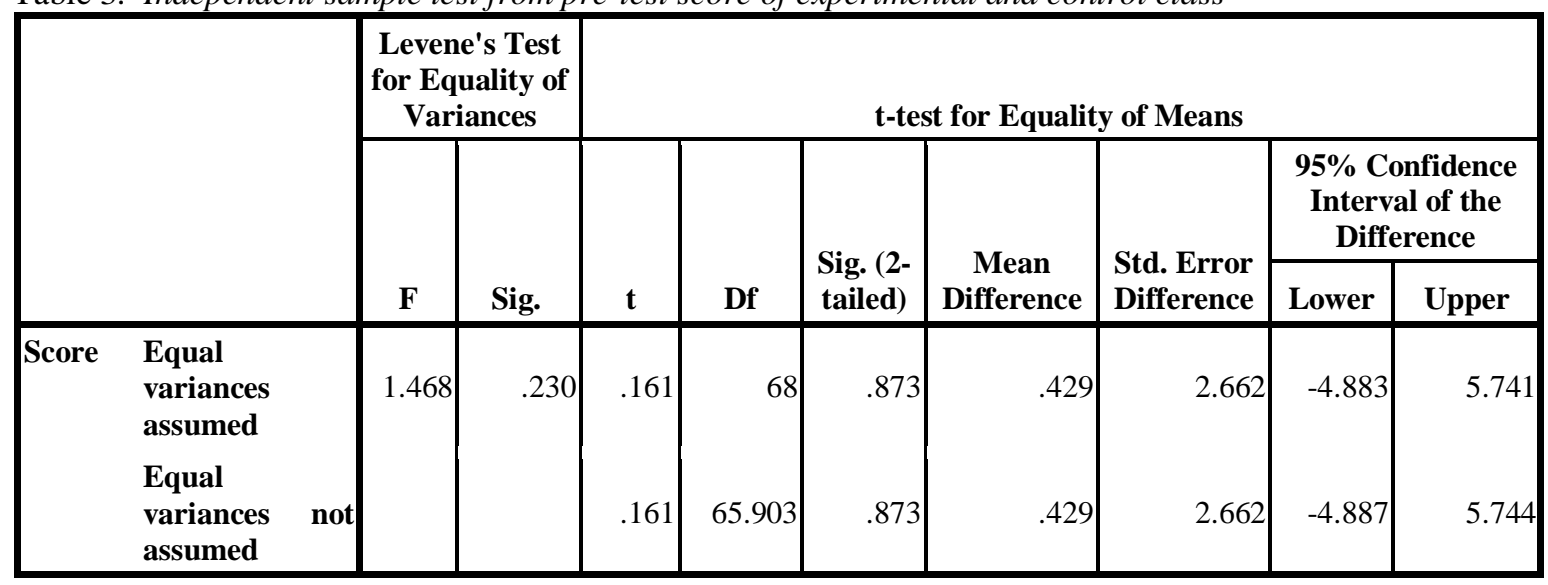

In determining whether there was or there was no significant difference of students' listening comprehension before being taught by using information transfer technique for experimental class and traditional teaching technique for control class, the writer used Independent t-test by using SPSS 16. The data were from students' listening pre-test score in both of experimental and control classes.

From the Table 3 above, the output of independent sample test showed that the t-test result was 0,161 , its df was 68 , significance was 0,873 , mean difference was 0,429 , standard error was 2,662 , the lower difference interval was $-4,883$ and the upper difference interval was 5,741 .

The result was intepreted by orienting number of significant. If probability $>0,05$, null hypothesis $\left(\mathrm{H}_{0}\right)$ is rejected. If probability $<0,05$ alternative hypothesis $\left(\mathrm{H}_{\mathrm{a}}\right)$ is accepted. Because the significance was $0,873>0,05$, thus, $\mathrm{H}_{0}$ was accepted while $\mathrm{H}_{\mathrm{a}}$ was rejected.

From the explanation above, it can be concluded that there was no significant difference of listening comprehension before being taught by using information transfer technique for experimental class and traditional teaching technique for control class of the first-year students at Al Madinah Islamic Junior High School Tanjungpinang. It meant that both experimental class and control class were quietly equal.

$\mathbf{H}_{0}$ 2: $\quad$ There was no significant difference of listening comprehension after being taught by using information transfer technique for experimental class and traditional teaching technique for control class. It can be seen through Table 4 below. 
Table 4. Independent sample test from post-test score of experimental and control class

\begin{tabular}{|c|c|c|c|c|c|c|c|c|c|c|}
\hline & \multicolumn{2}{|c|}{$\begin{array}{l}\text { Levene's Test } \\
\text { for Equality } \\
\text { of Variances } \\
\end{array}$} & \multicolumn{7}{|c|}{ t-test for Equality of Means } \\
\hline & & \multirow[b]{2}{*}{$\mathbf{F}$} & \multirow[b]{2}{*}{ Sig. } & \multirow[b]{2}{*}{$\mathbf{t}$} & \multirow[b]{2}{*}{ Df } & \multirow{2}{*}{$\begin{array}{l}\text { Sig. (2- } \\
\text { tailed) }\end{array}$} & \multirow{2}{*}{$\begin{array}{c}\text { Mean } \\
\text { Difference }\end{array}$} & \multirow{2}{*}{$\begin{array}{l}\text { Std. Error } \\
\text { Difference }\end{array}$} & \multicolumn{2}{|c|}{\begin{tabular}{|c|c|}
$5 \%$ Confidence \\
Interval of the \\
Difference
\end{tabular}} \\
\hline & & & & & & & & & Lower & Upper \\
\hline Score & $\begin{array}{l}\text { Equal variances } \\
\text { assumed }\end{array}$ & .606 & .439 & 3.124 & 68 & .003 & 9.000 & 2.881 & 3.251 & 14.749 \\
\hline & $\begin{array}{l}\text { Equal variances } \\
\text { not assumed }\end{array}$ & & & 3.124 & 67.846 & .003 & 9.000 & 2.881 & 3.250 & 14.750 \\
\hline
\end{tabular}

In determining whether the there was a difference of the students' listening comprehension after being taught by using information transfer technique for experimental class and traditional teaching technique for control class, the writer used Independent t-test by using SPSS 16. The data were from students' listening post-test scores in both of experimental and control class.

From the Table 4 above, the output of independent sample test showed that the t-test result was 3,124 , its df was 68 , significance was 0,003 , mean difference was 9,000 , standard error was 2,881, the lower difference interval was 14,749 and the upper difference interval was 14,750 .

The result was intepreted by orienting number of significance. If probability $>0,05$, null hypothesis $\left(\mathrm{H}_{0}\right)$ is rejected. If probability $<0,05$ alternative hypothesis $\left(\mathrm{H}_{\mathrm{a}}\right)$ is accepted. Because the significance was $0,003<0,05$, thus, $\mathrm{H}_{\mathrm{a}}$ was accepted while $\mathrm{H}_{0}$ was rejected.

From the data showed above, therefore, it can be concluded that $H_{a}$ was accepted and $H_{o}$ was rejected. In the other word, there was a significant difference of listening comprehension after being taught by using information transfer technique for experimental class and traditional teaching technique for control class of the first year students at Al Madinah Islamic Junior High School Tanjungpinang.

$\mathbf{H}_{0} 3$ : There was no significant effect of using information transfer technique toward students' listening comprehension. It can be seen through Table 3 below.

Table 5. Paired sample test

\begin{tabular}{|c|c|c|c|c|c|c|c|c|}
\hline & \multicolumn{5}{|c|}{ Paired Differences } & \multirow[b]{3}{*}{$\mathrm{T}$} & \multirow[b]{3}{*}{ df } & \multirow{3}{*}{$\begin{array}{l}\text { ig. } \\
\text { tailed) }\end{array}$} \\
\hline & \multirow[b]{2}{*}{ ean } & \multirow{2}{*}{$\begin{array}{c}\text { td. } \\
\text { Deviation }\end{array}$} & \multirow{2}{*}{$\begin{array}{r}\text { Std. } \\
\text { Error Mean }\end{array}$} & \multicolumn{2}{|c|}{$\begin{array}{l}95 \% \text { Confidence Interval } \\
\text { of the Difference }\end{array}$} & & & \\
\hline & & & & Lower & Upper & & & \\
\hline $\begin{array}{ll}\text { air } & \text { osttes } \\
1 & \mathrm{t} \\
& \text { prete } \\
& \text { st }\end{array}$ & 2.571 & $\begin{array}{r}8 \\
.521\end{array}$ & $\begin{array}{r}1.44 \\
0\end{array}$ & 9.644 & 15.498 & $\begin{array}{r}8 \\
.728\end{array}$ & 34 & \\
\hline
\end{tabular}


In determining whether there was significant effect of using information transfer technique toward students' listening comprehension, the writer used Paired sample t-test by using SPSS 16. The data were taken from students' listening pre-test and post-test score in experimental class.

The result can be intepreted by orienting number of significance. If probability $>0,05$, null hypothesis $\left(\mathrm{H}_{0}\right)$ is rejected. If probability $<0,05$ alternative hypothesis $\left(\mathrm{H}_{\mathrm{a}}\right)$ is accepted. Because the significance was $0,000<0,05$, thus, $\mathrm{H}_{\mathrm{a}}$ was accepted while $\mathrm{H}_{0}$ was rejected.

Therefore, it can be concluded that $H_{a}$ was accepted and $H_{o}$ was rejected. In other words, there was significant effect of using information transfer technique toward listening comprehension of the first year students at Al Madinah Islamic Junior High School Tanjungpinang.

\section{Conclusion}

The results and findings indicate that there was a significant effect of using Information Transfer technique toward students' listening comprehension. It was showed by the paired sample t-test score of the experimental that was higher than the level of significance. The writer then concludes that this technique can improve the students' listening comprehension better. Then, this technique can also be implemented to vary teachers' ways in teaching English.

\section{References}

Arikunto, Suharsimi. (2009). Dasar-Dasar Evaluasi Pendidikan. Jakarta: Bumi Aksara.

Brown, Gillian, \& Yule, George. (1999). Listening to Spoken Language. New York: Longman.

Brown. H. Douglas. (2000). An Interactive Approach to Language Pedagogy. San Fransisco: Longman.

(2003). Language Assessment Principles and Classroom Practices. San Fransisco: Longman.

. (1994). Teaching by Principles: An Interactive Approach to Language Pedagogy. New Jersey: Prentice Hall Regents.

Buck, Gary. (2001). Assessing Listening, Cambridge: Cambridge University Press.

Celce Murcia, Marianne Ed. (2001). Teaching English as Second or Foreign Langauge. Boston: Heinle \& Heinle -Thomson Learning.

Creswell, John W. (2008). Educational Research Planning, conducting, and Evaluating Quantitive and Qualitative Research. New Jersey: Prentice Hall.

Dale, Paulette \& Wolf, James C. (2006). Speech Communication Made Simple Third Edition. New York: Addison Wesley Longman.

Djuharie, Otong Setiawan. (2007). Genre. Bandung: Yrama Widya. 
Gay L.R Et.Al. (2000). Educational Research. Competencies for Analysis and Application : Prentice-Hall, Inc.

Halimah NST.,S.Pd. Silabus Bahasa Inggris Al Madinah Islamic Junior High School Tanjungpinang 2012/2013, Pekanbaru (Unpublished)

Hartono. (2008). Statistik untuk Penelitian. Yogyakarta: Pustaka Pelajar.

Hornby, A.S. (2000). Oxford Advanced Learner's Dictionary. Oxford: Oxford University Press.

Huges, Arthur. (2003). Testing for Language Teacher $2^{\text {nd }}$ Edition. New York: Cambridge University Press.

Longman. (2001). Educational English Dictionary. Edinburgh: Pearson Education.

Mc. Knight, K.S. (2010). The Teacher's Big Book of Graphic organizer. San Fransisco: Jossey Bas. http://www.library.nu (Retrieved on September 15, 2011).

Nation, I. S. P. (1977). The Combining Arrangement: Some Techniques. Modern Language Journal. New Zealand: Victoria University of Wellington.

Nation I. S. P \& Newton, Jonathan. (2009). Teaching Esl/Efl Listening and Speaking. New York : Routledge.

Nation, Paul. (1988). Using Techniques Well: Information Transfer. Guidelines 10 Journal. New Zealand: Victoria University of Wellington.

Nunan, David. (2003). Practical English Language Teaching. New York: McGraw Hill Company.

Richard, Jack C., Platt, John, \& Platt, Heidi. (1999). Language Teaching and Applied LinguisticsLongman Dictionary. England: Pearson Educato Limited.

Riduwan. (2008). Rumus dan Data Dalam Analisa Statistika. Bandung: Alfabeta.

Sacroba, Arif. (1999). The Teaching of Listening. The Internet TESL Journal. Vol. V. No. 12.

Siregar, Sofyan. (2013). Statistik Parametrik untuk Penelitian Kuantitatif. Jakarta: Bumi Aksara.

Sudarwati, Th. M. (2007). Look Ahead 1 an English Course for Senior High School Students Year $X$. Jakarta: Erlangga.

Sugiyono. (2011). Statistika untuk Penelitian. Bandung: Alfabeta.

Sumiati. "The effect of using three step interview strategy toward students listening comprehension at the first year of state senior high school Dharma Pendidikan Kampar District of Indragiri Hilir Regency". Unpublished Undergraduate Thesis, Pekanbaru: UIN Suska Riau, 2012.

Syafii, Muhammad. (2011). From A Paragraph to A Research Report: A Writing of English for Academic Purposes: Pekanbaru. 
Thi, Tra Thi Diem and Loan, Nguyen Thi. (1995)` Information Transfer Use in English Teachin.

Truon, Vien. (1999). An Application of the Information-Transfer Technique in Teaching Reading Comprehension in Vietnamese Secondary School Classrooms of English. Journal of Science and Education. Hue: Hue University, College of Education`

Underwood, Mary. (1989). Teaching Listening. New York: Longman.

Yin Mee, Mac. (1990). Teaching Listening an Overview. The University Malaya Journal. Vol.XIX. University of Malaya: The English Teacher. 